Article

\title{
Diagnostics and mapping of geoecological situations in the permafrost zone of Russia
}

\author{
Nellie Tumel ${ }^{1}$ and Larisa Zotova ${ }^{2 *}$ \\ ${ }^{1}$ Faculty of Geography, Lomonosov Moscow State University, Moscow, Russia; ntumel@mail.ru \\ ${ }^{2}$ Faculty of Geography, Lomonosov Moscow State University, Moscow, Russia; zotlar@mail.ru \\ *Author to whom correspondence should be addressed \\ Correspondence: zotlar@mail.ru, Tel.: +79168023732
}

Received: date; Accepted: date; Published: date

\begin{abstract}
The diagnostics of natural landscapes geoecological state in the course of the permafrost zone economic development should be based on the assessment of the destructive cryogenic processes formation. It is expedient to consider it in terms of landscapes resistance to cryogenic processes increase. The choice of lithocryogenic stability parameters is substantiated. These are: permafrost distribution over the area, its annual mean temperature and ice content, protective properties of the vegetation and etc. Cryogenic processes activation is estimated with regard to their area, development rate and attenuation, natural landscapes damage, hazard for engineering facilities operation. The assessment procedure, and the way of improving expert numerical scores are shown. At Geography Faculty of Lomonosov Moscow State University, the authors have developed a number of the approved methods of making evaluation maps of different scales applying the methods of landscape indication, modern methods of space images decoding, methods of expert scores, the method statistical calculations and methods of spatial GIS-analysis. The technique of Atlas geo-information mapping on the landscape basis has been introduced in seven atlases at scales from 1:3 000000 to 1:20 000 000. These maps are widely used in design and survey organizations and in education.
\end{abstract}

Keywords: geoecological situations, permafrost zone, cryolithozone, cryogenic processes, landscapes stability, geoinformation mapping.

\section{Introduction}

The diagnostics of geoecological situations in the cryolithozone demands the analysis of the following main parameters of the permafrost: the distribution area, the annual mean temperature and ice content degree. The permafrost area shapes the geography of geoecological hazards emergence (north - south; west east). The annual mean temperature influences the stability of permafrost and cryogenic landscapes. The lower the temperature, the less the geoecological hazard, other things being equal. The development hazard is directly proportional to the ice content degree of permafrost. With its increase, the geoecological consequences of the economic development grow.

While assessing geoecological situations in the north territories, the following parameters are important: the permafrost distribution on area and profile, its annual mean temperature and thickness, the cryogenic structure of the upper part of the permafrost, cryogenic forms of the relief, the layer of seasonal thawing and freezing. Of importance is the position of permafrost limits as boundaries of permafrost quality changes, its unstable states. 


\section{Materials and Methods}

\subsection{Basic mapping materials}

As sources for making small-scale maps for the cryolithozone territory, four permafrost maps should be used. These are: Geocryological Map of the USSR (scale 1: 2.5 million (1997)) [1], Geocryological Map of the USSR (scale 1: 5 million (1970)) [2], Circum Arctic Map of Permafrost and Ground Ice conditions (scale 1: 10 million (1997)) [3], Cryolitological Map of the USSR (scale 1: 4 million (1985)) [4]. The most comprehensive source of detailed characteristics of permafrost conditions all over Russia is the Geocryological Map of the USSR (scale of 1: 2.5 million) [1]. From this map we used the data on the permafrost temperature and its thickness, lithological composition, genesis, cryogenic structure and ice content of permafrost that were coordinated with a landscape map.

For displaying the natural background in which various geoecological situations are being formed, it is necessary to analyze a number of small-scale permafrost maps, made on a uniform landscape basis, on a geosystems grid of various ranks. In geographical atlases of the recent two decades [5-11], the landscape map (scale 1:15 000000 (fig. 1)),

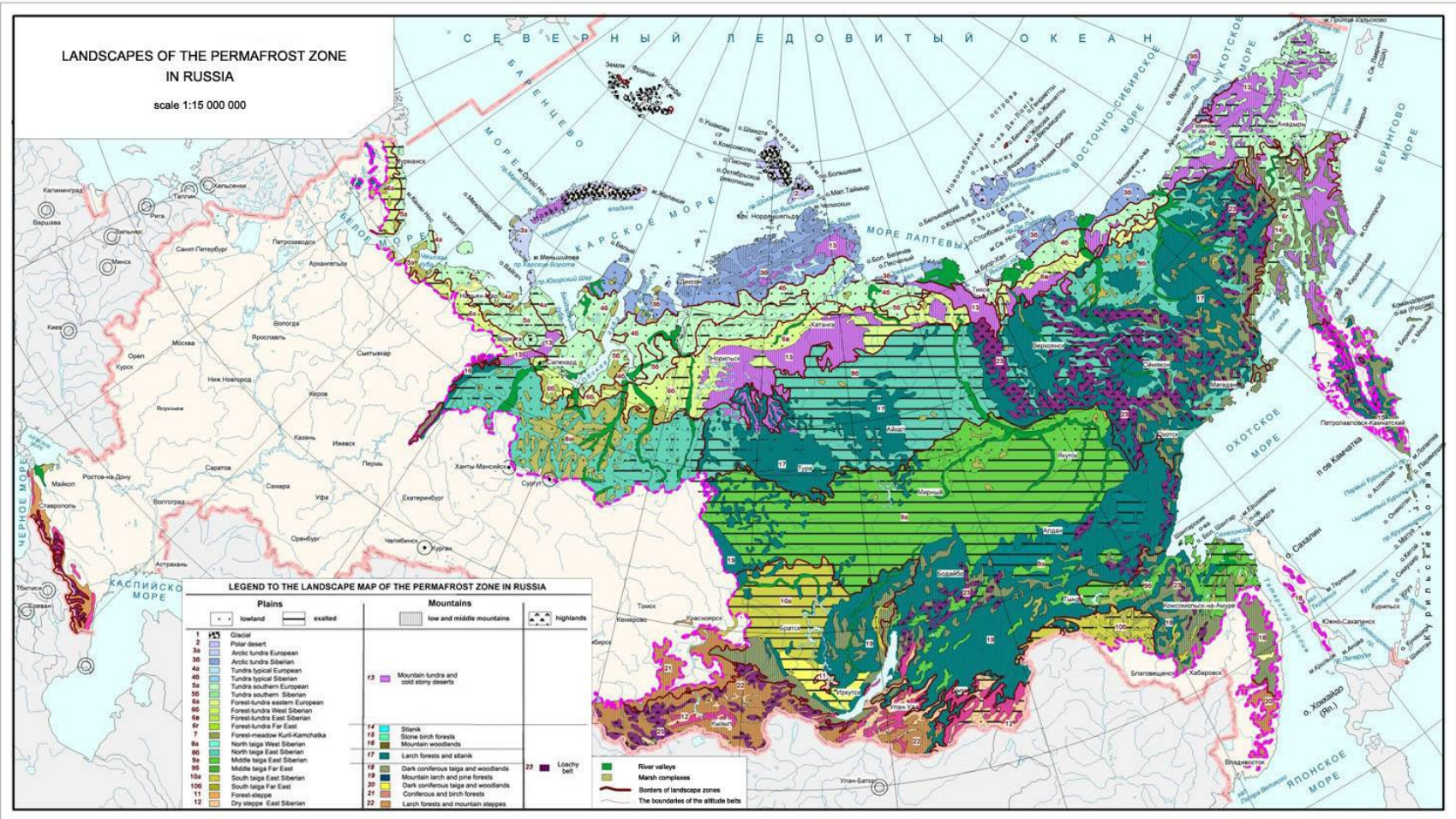

Figure 1. Landscape map of the Permafrost zone in Russia

i.e. the generalized Landscape Map (scale 1:4 000 000) for the territory of Russia edited by A.G. Isachenko [12] was the main landscape information source. In legend to this map (fig. 2), the landscape zone types are shown in horizontal ranks.Vertical columns correspond to landscape kinds, i.e. to genetic types of a relief and lithological differences of rocks. The tabular legend facilitates the selection of landscapes characteristics separate components on the lithogenic basis, relief, vegetation in zone and sector aspects that are necessary for permafrost situation understanding. 


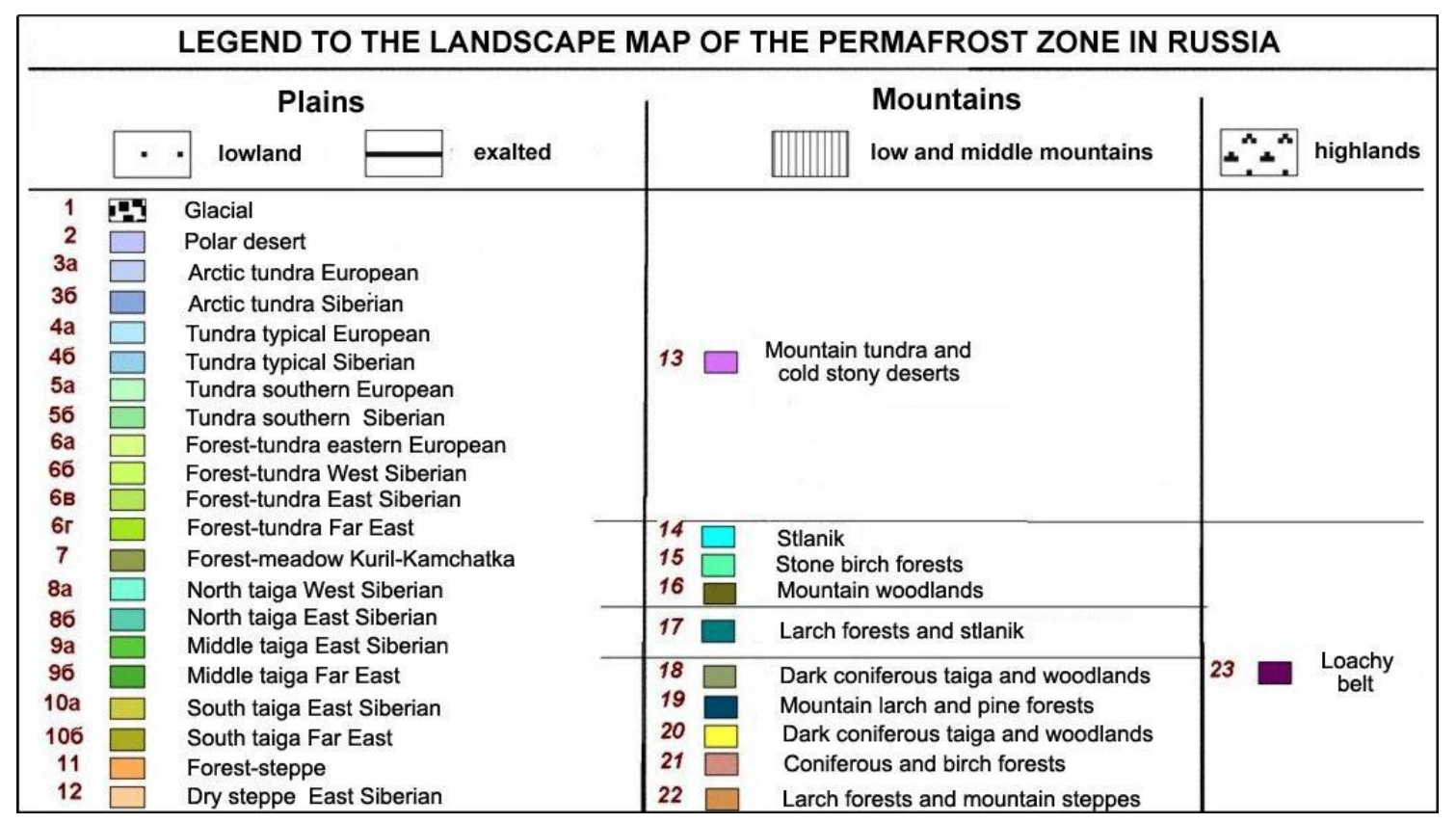

Figure 2. Legend to the landscape map of the Permafrost zone in Russia

Let us consider two basic maps of the section "Permafrost" published in the Ecological Atlas of Russia [5]. These are maps of scale 1:20 000 000: "Permafrost of Russia" and "Seasonal freezing and thawing".

On the Permafrost map of Russia (fig. 2), four main types of permafrost distribution are shown: continuous, discontinuous, massive-island and island.

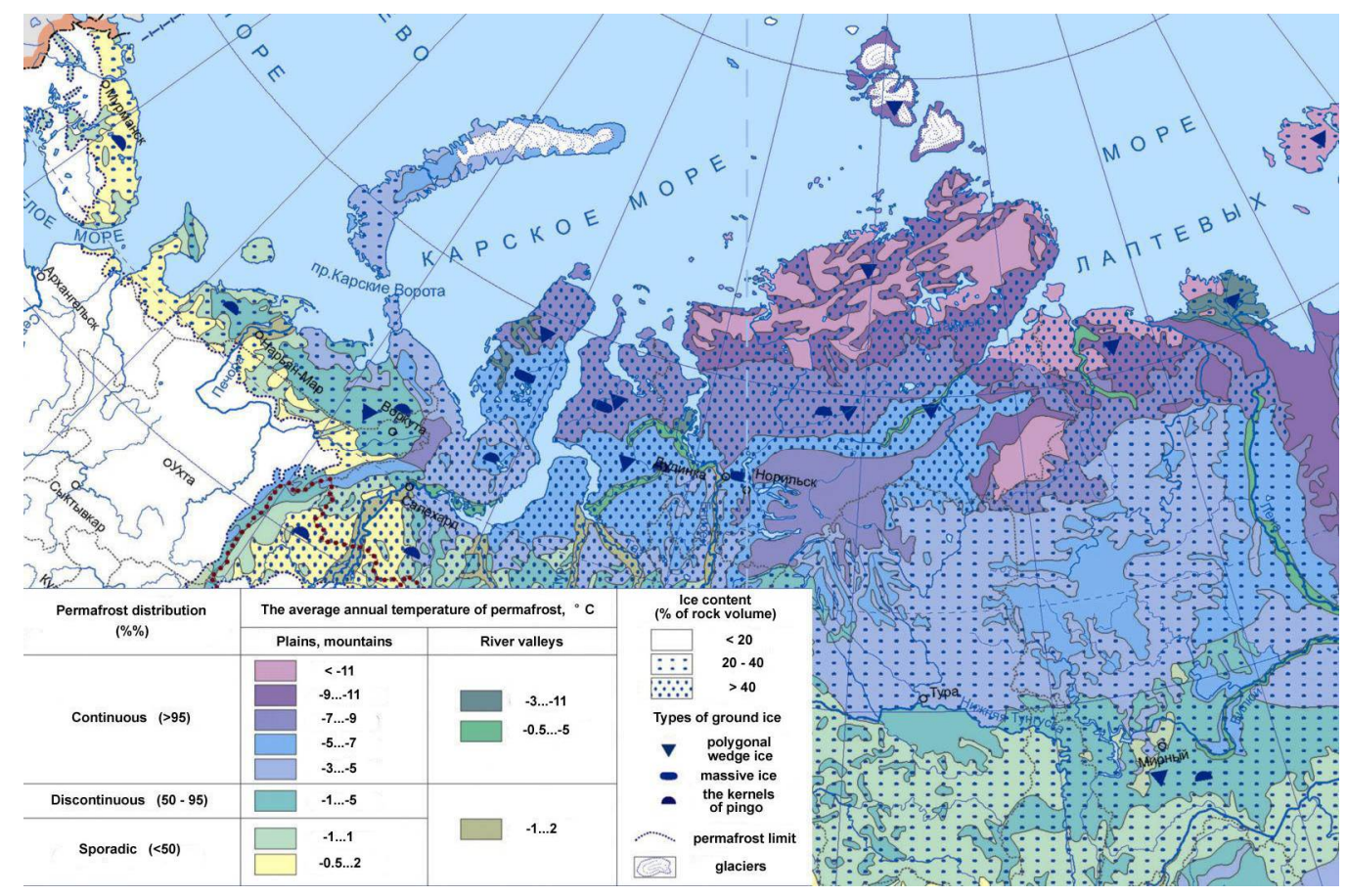

Figure 2. Map fragment "Permafrost of Russia", scale 1:20 000000

Within each type, the territories with different values of annual mean temperature of permafrost are allocated due to the distribution area. The temperature on plains and plateaus increases first of all from the north to the south. In mountainous landscapes the temperatures are lower, than on the adjacent plains. The greatest variety of temperatures is in the continuous permafrost zone: from $-11^{\circ} \mathrm{C}$ to $-3^{\circ} \mathrm{C}$. 
In the discontinuous permafrost zone, it is difficult to differentiate the permafrost temperature field within the map scale. This type of permafrost is most widespread in mountains and uplands of the south and east of the Russian cryolithozone. Massive-island and island permafrost types are characterized by the temperatures not below $-1^{\circ} \mathrm{C}$, and the thawed areas have temperature $1-2^{\circ} \mathrm{C}$ here. The map shows three main permafrost types due to the ice content degree. Thus, the low-icy permafrost $(<20 \%)$ is mainly observed in the cryogenic eluvium of the highlands and plateaus, in the upper part of the fractured rocks and the sands. The mid-icy permafrost $(20-40 \%)$ is represented by sandy and loamy differences within denudation plains. The highly icy permafrost $(>40 \%)$ is most often observed within low accumulative plains with loamy and sandy ground. The signs indicate the areas of monomineral ice massifs distribution, such as polygonal-vein ice massifs, the kernels of frost heave mounds and ice beds [13,14].

The second important map, necessary for geoecological research, is the Seasonal Freezing and Thawing Map (fig. 3). For its making not only the Landscape Map by A.G. Isachenko [12], but also the Geocryologic Map of the USSR, scale 1: 2500000 [1] were used to the full extent along with the results of regional research of seasonal freezing and thawing from publications, funds data, the authors' personal archive.

It is worth mentioning that the layer of seasonal freezing and/or thawing (so-called "active layer") is the first permafrost horizon from the surface, in which ecologically hazardous cryogenic processes take place. The change of its thickness is integrated in the manifestation of cryogenic processes and serves as an indicator of their activation. During engineering research and calculations, this parameter has paramount importance and, along with ground temperature, their ice content (or humidity), is used for ensuring reliability of buildings, facilities, communications operation/maintenance during the solution of specific engineering-geological objectives.

The peculiarity of the map Seasonal Freezing and Thawing is in the fact that within the borders of the cryolithozone of Russia not only seasonal permafrost thawing is evaluated, but seasonal freezing in taliks too. The area of the latter increases with the approach to the southern permafrost limit. Taliks are almost absent in the continuous permafrost, and in the south of cryolithozone permafrost occupies no more than 5-10\% of the area. Therefore, in the discontinuous permafrost within the same landscape, small-scale maps display both depths: of seasonal thawing and of seasonal freezing.

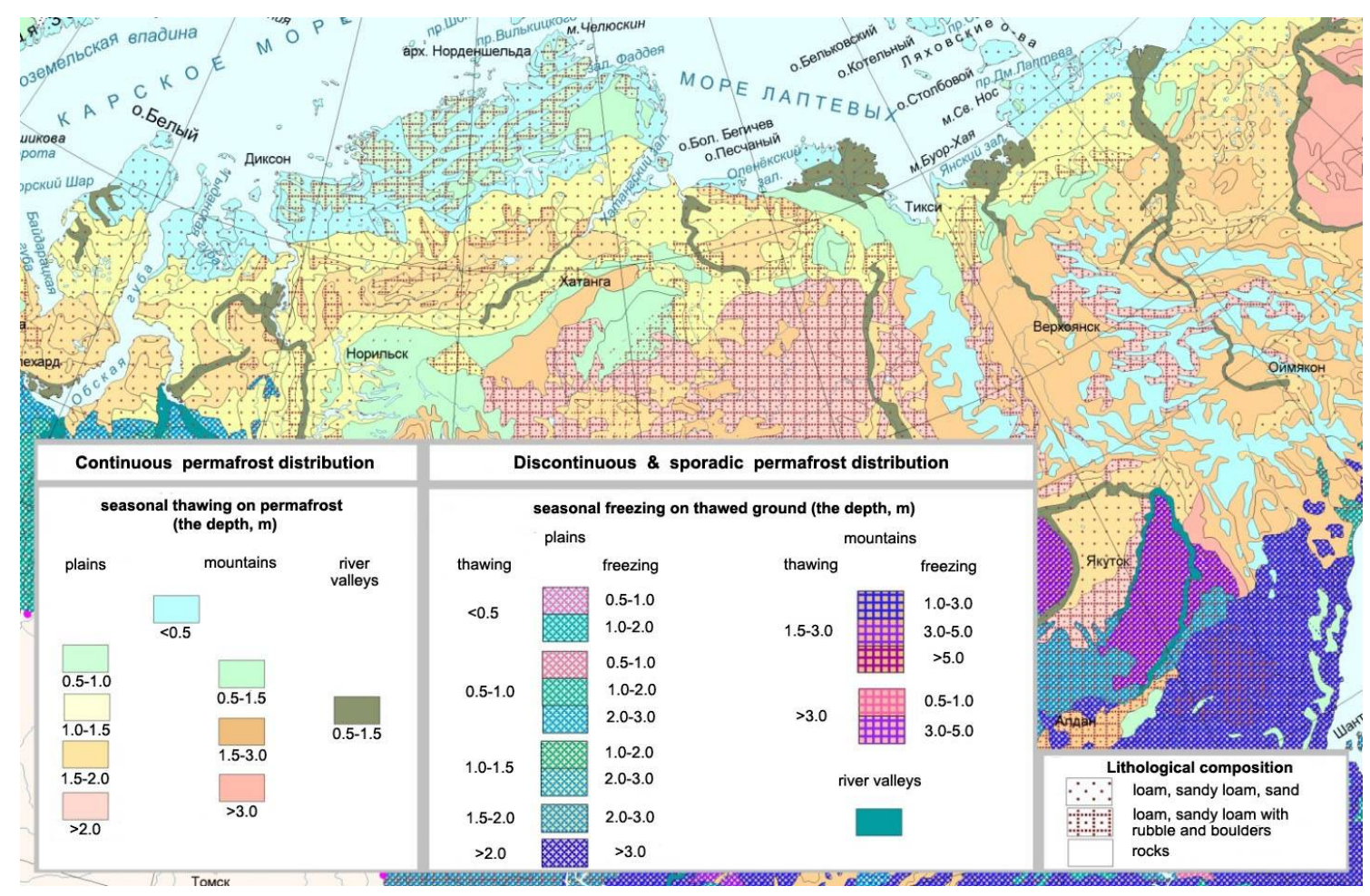

Figure 3. Legend and map fragment Seasonal freezing and thawing 
The allocation of two large fields of the seasonal freezing and thawing distribution is the basis for the creation of the legend (fig. 3) and graphic design of a map. The scale is carried out for each of them. The influence of a relief is shown by creating separate scales for their different constituents: plains, mountains, river valleys. The whole depth range of seasonal freezing and thawing is subdivided into three types: small (up to $0,5 \mathrm{~m}$ ) where the majority of factors interferes with the processes of seasonal freezing and thawing; average (to $1.0-1.5 \mathrm{~m}$ ) with relative compensation of the factors fostering and interfering the process; deep (more than $1.5 \mathrm{~m}$ ) where the most part of factors fosters the process. The degree of the geoecological hazard increases from the deep active layer to the shallow one, as in this direction the hazard of damaging natural environment under anthropogenic impacts increases [15].

The diagnostics of geoecological situations is based on geographical features of active layer depths distribution. In continuous permafrost zone, only the depth of seasonal thawing is mapped, which in general is subject to latitudinal and altitudinal zonation. The thawing of less than $0.5 \mathrm{~m}$ is shaped by severe climatic conditions of the Arctic and is observed in the polar deserts of the Arctic Ocean islands and on the loaches of ridges of the Northeast of Russia. The thawing from 0.5 to $1.0 \mathrm{~m}$ is characteristic of peats and peaty soils of the lake and marsh landscapes elsewhere. The average thawing due to the depth (intervals of 1.0-1.5 m and 1.5$2.0 \mathrm{~m}$ ) is found in the associated soils of tundra and forest-tundra landscapes within the European North, Western Siberia peninsulas, in the north of the Taimyr Lowland, the seaside lowlands of the Northeast of Russia. The deep, more than 2 meters, thawing is localized in the sandy landscapes created by ancient sea, alluvial, and lake -glacial sediments. In the mountains, according to the landscape zonation and reduction of absolute heights, the depth of thawing increases.

\subsection{Methodology of estimating research and mapping}

The geosystems stability is one of the fundamental concepts of physical geography and geoecology. The cryogenic landscapes resistance to surface damage is understood as the ability to resist to anthropogenic activation of cryogenic processes that may lead to irreversible deterioration of the environmental situation and unacceptable deformations of engineering structures [16]. Cryogenic processes is the key indicator of northern landscapes reaction to external influences [17].

The mechanical damage arising during the engineering facilities functioning and mining are widespread in the cryolithozone. It is also necessary to refer the typical anthropogenic influence of the North, , as overgrazing of reindeer pastures, as well as deforestation and burning. All these violations intensify the development of thermokarst, solifluction, deflation, foster the expansion of the boggy areas.

The concept of geo-ecological research is based on the leading factors identification of the landscapes lithocryogenic state, that influence the landscape stability decrease and, as a result, cryogenic processes activation [16]. Thus, for making the Map of landscape stability of Western Siberia cryolithozone, scale 1: 4 000000 [18], six factors influencing directly the potential activation of cryogenic processes, connected with phase transitions of water, were selected: dissected relief; ground composition; permafrost temperature; ice content (humidity) of the ground; the degree of vegetation recoverability; relative change in the active layer. In the works $[15,17,18]$ their choice is explained.

The evaluation procedure includes:

- selecting the main factors that influence landscapes resistance to loadings (cryogenic processes activation);

- drawing up the table of factors ranging;

- assigning numerical scores to each landscape in accordance with the table;

- ranking of all landscapes due to vulnerability to the economic development, taking into account the calculated indexes;

- evaluative mapping.

With this technique, the so-called engineering permafrost (lithocryogenic) stability maps are made on a landscape basis. Depending on the regional specifics and the scale of the research, the number and spectrum of the estimated factors may varies.. For example, for Central Yakutia it is necessary to consider a number of bioclimatic factors [19], crown density of a forest stand, etc. [15]. Owing to the developed traditions in geoecological estimations, expert scores are widely used for the comparative characteristic of the objects. They are simply summed up or arithmetic mean values (rarely -the geometric mean values) are calculated. The 
calculation-statistical method of miltifactorial landscape biotic and lithocryogenic basis properties correlation analysis can also be used.

At first, the integral impact of all landscape stability factors was estimated by total score [17]. Summing points may be used in the regional survey research, though it has serious limitations due to the fact that points lack dimensionality [20]. But it is easily solved if the points are appointed against the background of a uniform interval 100 cent scale $[15,21]$.

The Intensity of the Cryogenic Processes

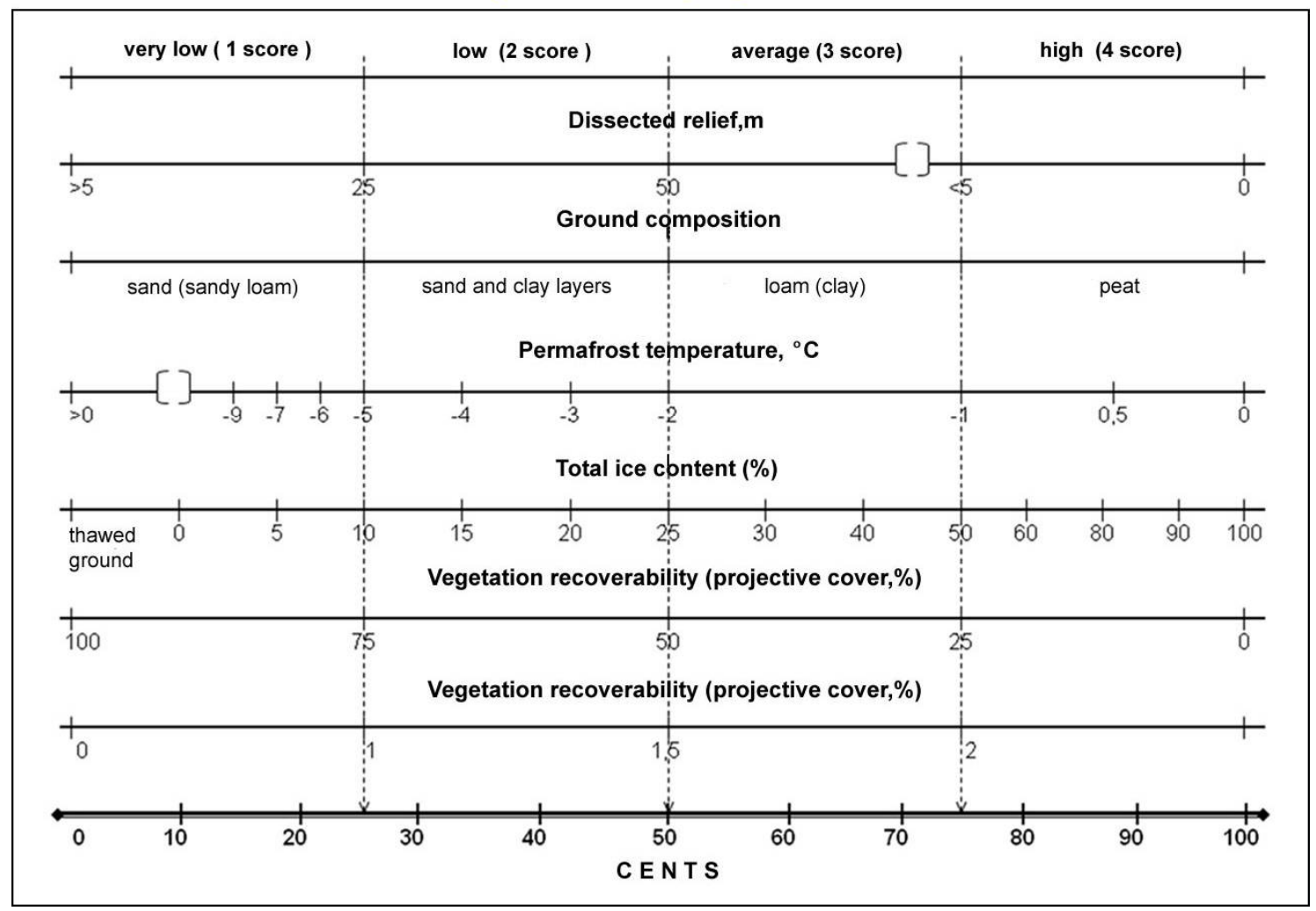

Figure 4 . The ratio of the estimated factor scales, affecting the intensity of cryogenic processes manifestation (Western Siberia)

In this case, the values of six indicators in cents due to which not the sum, but the geometric mean, that can be called hazard coefficient $C o$, is calculated, correspond to each landscape. The less the value of $C o$, the more steady the landscape should be considered. Thus, for splitting all landscapes into clusters due to stability, two techniques were tested: simple points summing and calculating the geometric mean value in cents.

Graphic figure 4 shows that of the greatest vulnerability for the economic development in this region ( in terms of destructive exogenous processes manifestation) are the landscapes with the values of six factors in the right part of the figure. These are plain slightly dissected landscapes with the annual mean ground temperature from $0^{\circ}$ to $-1^{\circ} \mathrm{C}$, made of peat, with more than $50 \%$ of ice content degree, with low recoverability of vegetation (projective covering of less than $20 \%$ ) in which the thickness of seasonal freezing-thawing layer may increase more than twice in case of mechanical damage of their surface.

Applying the landscape basis and the database with particular values, each factor can be displayed as a separate thematic layer (ice content degree, ground temperature, etc.) and further to use overlaying. It is rather complicated and is not always justified. To simplify mapping, the express assessment of diverse factors with integrated indexes calculation is carried out: permafrost stability coefficient - PSC, coeffi ecological hazard coefficient - EHC, hazard coefficient $C_{o}$ and others [13]. In large-scale research, it is expedient to use the multiple-factor correlation analysis of the estimated factors which, first, allows us to estimate the importance of a particular factor and, secondly, brings closer the quality standard to the quantitative one. 


\subsection{Evaluation of geoecological situations at local level}

For the assessment of the formation of various geoecological situations, the table matrix (fig. 5) is developed, on the horizontal axis there are groups of stability according to gradation of the calculated indices, and on the vertical axis there are load categories [22,23].

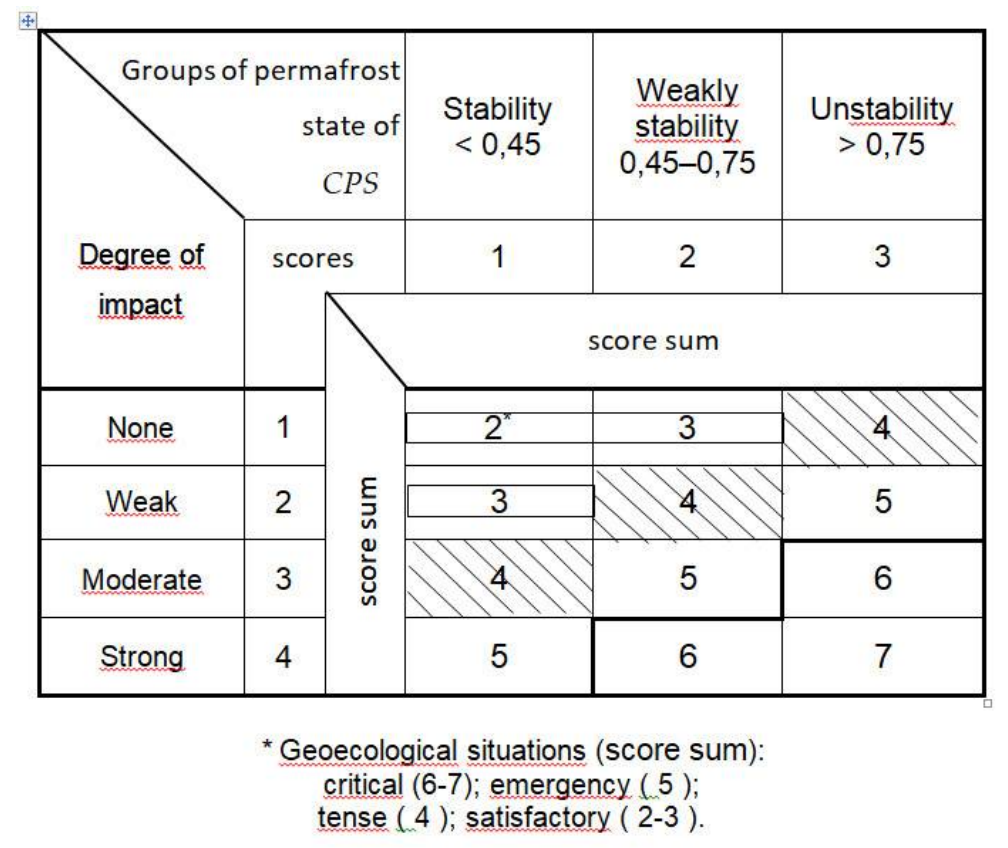

Fig. 5 Evaluation of Geoecological Situations Shaping

The categories of anthropogenic loading are ranged due to the types and sorts of mechanical damage, residual deer capacity, vegetation recovery rate, a share of the damaged lands, etc. The type of a possible situation is determined by the score in each cell of a matrix. As a result, all cells unite in four groups, forming the types of geoecological situations according to regulatory documents of the Ministry of Natural Resources and Environmental Protection of the Russian Federation on nature conservation: from rather satisfactory to crisis $[15,23]$.

Each situation is characterized by a set of exogenous processes of different intensity. Thus, typical processes of a crisis stage in the forest-tundra of Western Siberia are: in peatlands - vein ices thawing out, deep thermokarst on polygonal -wedge ices, peat block subsidence, intensive thermal erosion in cracks, ice thawing out in frost mounds and their turning into lakes. In bogs with low-center polygons - progressive swamping, thermokarst, seasonal and long-term frost heave. Frost cracking - thermal erosion - is activated in cracks, and intensive deflation is developed with the formation of deflation basins in tundras on icy and icerich dusty sands with topsoil cover removed [22].

For making the maps of geoecological situations (fig. 6) the map of landscapes permafrost stability is compared to the map of anthropogenic loading via overlaying [22]. 


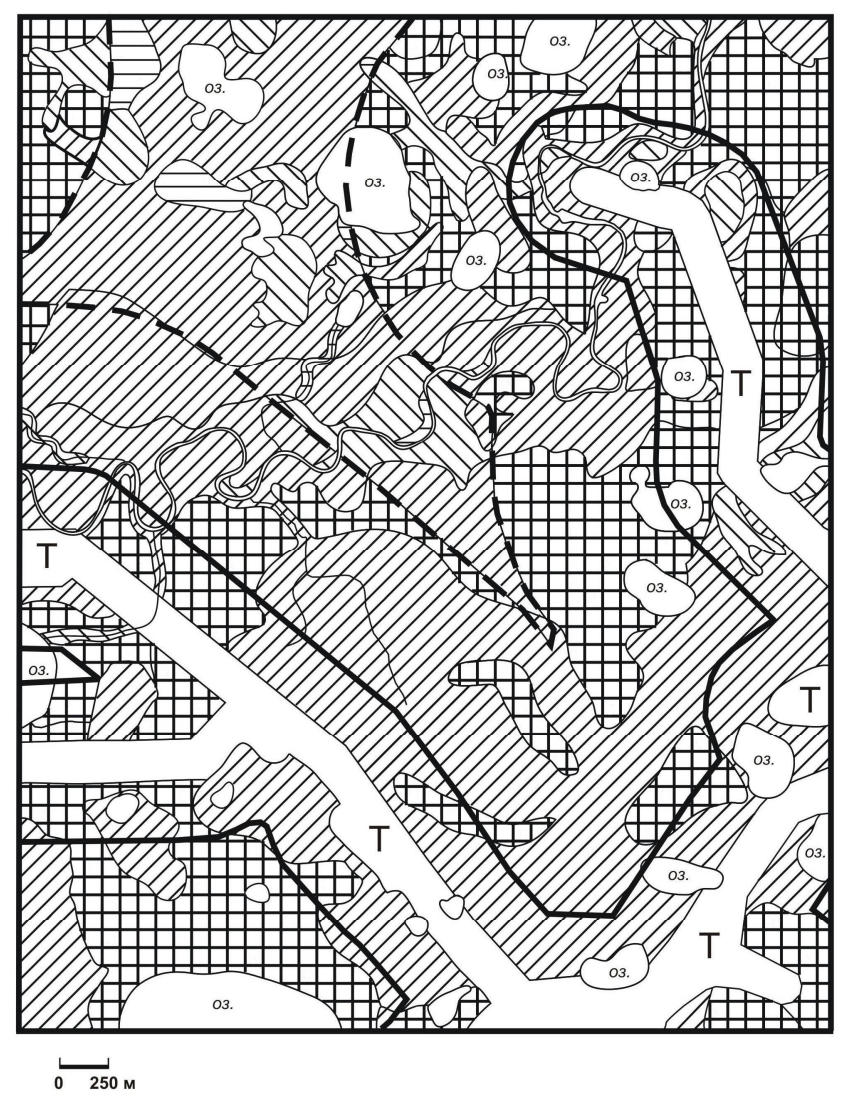

Situation type (by score sum)

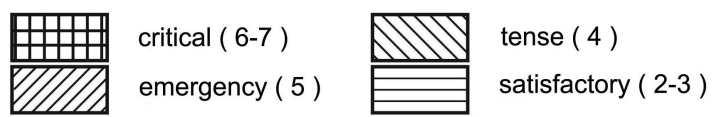

The boundaries of anthropogenic impact zones:

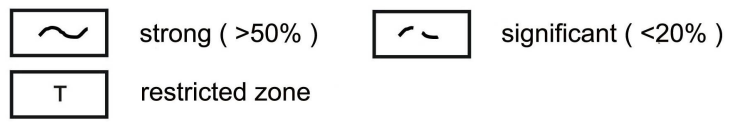

Figure 6. Segment of the map of geoecological situations of the Yamburg deposit

The duration of geoecological situations existence (and, therefore, the degree of cryogenic processes activation) depends on the stages of territory development. The scheme (fig. 7) shows that rather satisfactory and intense situations last from 3-5 to 10 years in accordance with the time when survey and construction works are taking place. Critical and crisis situations arise during the deposit operation. Further destruction of the natural complex and activation of the processes occur within the first 5-10 years of commercial production of hydrocarbons. Then, there comes their gradual attenuation both for the natural reasons, and because of the taken engineering and meliorative measures [24]. 


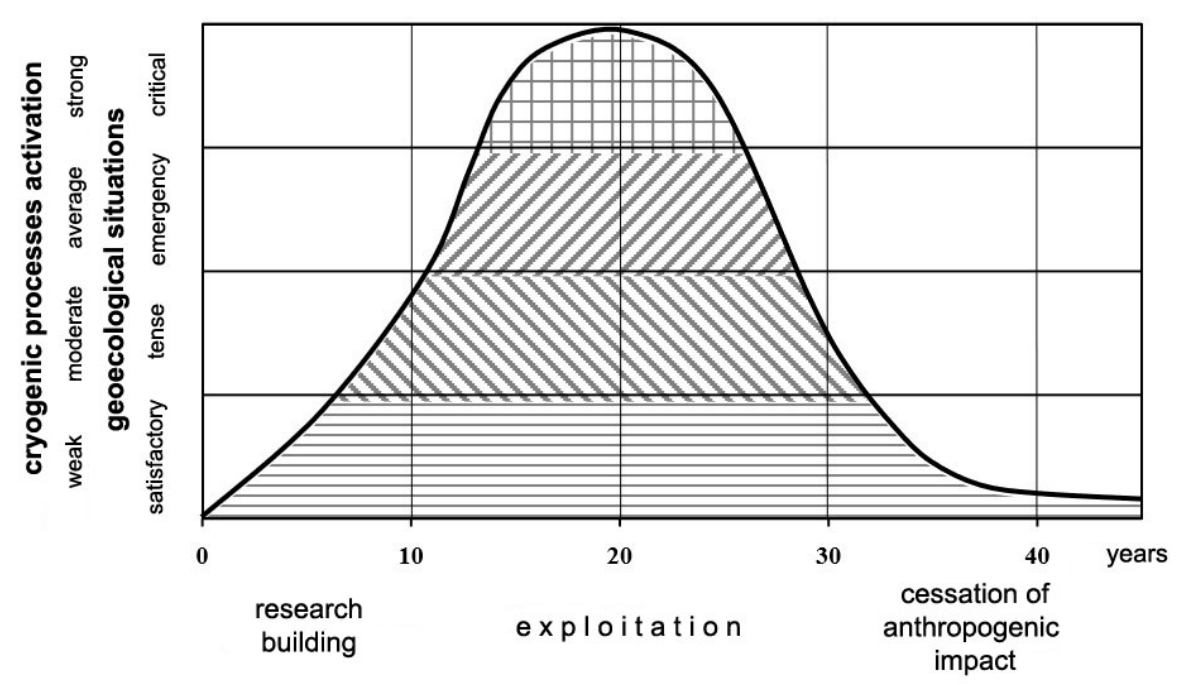

Figure 7. Types of geoecological situations depending on the stages of development and intensity of cryogenic processes manifestation

\subsection{Factors of cryogenic processes activation}

The main complex of ecologically dangerous cryogenic processes is comprised of two groups: the periods which are becoming more active in summer and in winter respectively [23]. It is important for diagnostics of geoecological situations as in summertime the vegetation ground cover is mainly investigated, in winter snow cover is considered. The first group of the processes is formed in the summer as a result of permafrost thawing. These are thermokarst, thermoerosion, thermoabrasion and solifluction, which under the increase of soil humidity moves into mass dislodging. The second group of the processes consists of in the autumnwinter period when water turns into ice, further cooling of soil takes place, so frost heave and frost cracking are observed. These processes combinations allow us to diagnose the emerging geoecological situations, to estimate the degree of their hazard both for the environment, and for anthropogenic facilities.

The assessment of the processes activation degree is based on the analysis of the following factors (Fig.8): cryogenic structure (or ice content) and temperature regime of the ground in the upper part to the depth, corresponding to the layer of annual heat transfer. Out of the "non-permafrost" components of nature the leading place belongs to vegetation and geological-geomorphological conditions [15]. 


\begin{tabular}{|c|c|c|c|c|c|}
\hline \multicolumn{3}{|c|}{ PERMAFROST } & \multicolumn{2}{|c|}{ VEGETATION } & \multirow[b]{2}{*}{$\begin{array}{l}\text { FACTORS-・IN- } \\
\text { FLUENCE·ON. } \\
\text { CRYOGENIC. } \\
\text { PROCESSESII } \\
\Rightarrow\end{array}$} \\
\hline $\begin{array}{c}\text { Ice } \cdot \text { content } \& \cdot \mathbb{I} \\
\text { types } \cdot \text { of } \cdot \text { ground } \\
\text { iceat }\end{array}$ & $\begin{array}{c}\text { The-aver- } \\
\text { age-annual- } \\
\text { tempera- } \\
\text { ture } \\
{ }^{\circ} \mathrm{C} \\
\end{array}$ & $\begin{array}{l}\text { Distribu- } \\
\text { tiona }\end{array}$ & $\begin{array}{c}\text { Protective II } \\
\text { properties } 1 \\
\text { म }\end{array}$ & $\begin{array}{c}\text { Self-healing II } \\
\text { vegetation } \\
\not\end{array}$ & \\
\hline Less $0,1 x$ & Below $\cdot 10 x$ & $\begin{array}{l}\text { Rare.II } \\
\text { islandar }\end{array}$ & $\begin{array}{c}\text { The-arctic.tundra. } \\
\text { - weaks }\end{array}$ & $\begin{array}{c}\text { The arctic } \cdot \text { tun- } \\
\text { dra.-badr }\end{array}$ & weaks \\
\hline $0,1-0,2 x$ & $-5 \ldots-10 x$ & Island $\cdot x$ & $\begin{array}{l}\text { Typical-tundra.- } \\
\text { moderatex }\end{array}$ & $\begin{array}{c}\text { forest-tundra.-. } \\
\text { moderater }\end{array}$ & moderatex \\
\hline $\begin{array}{c}0,2-0,4 \\
\text { Epigenetic.mas- } \\
\text { sive } \cdot \text { vein } \cdot \text { ice } \mathbb{I} \\
\not\end{array}$ & $\begin{array}{l}-3 \ldots-5 \\
0 \ldots+2\end{array}$ & $\begin{array}{l}\text { Massive II } \\
\text { islandx }\end{array}$ & $\begin{array}{l}\text { South.tundra.- } \\
\text { goodr }\end{array}$ & Taiga.-.good $x$ & averagex \\
\hline $\begin{array}{c}0,4-0,6 \\
\text { polygonal-wedge } \\
\text { ice, frost } \cdot \text { heave. } \\
\text { mound }\end{array}$ & $-3 \ldots-1 x$ & $\begin{array}{l}\text { Discon- } \\
\text { tintous } \\
\end{array}$ & $\begin{array}{l}\text { forest-tundra.and } \\
\text { taiga--.significant }\end{array}$ & $\begin{array}{c}\text { Tundra.-sig- } \\
\text { nificanta }\end{array}$ & strong \\
\hline 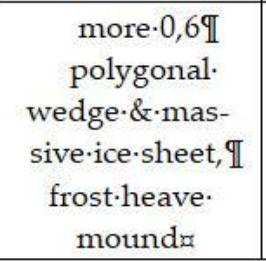 & $0 \ldots-1 \not x$ & $\begin{array}{l}\text { Continu- } \\
\text { ousa }\end{array}$ & $\begin{array}{c}\text { Marsh-landscapes. } \\
-\cdot \mathbb{I} \\
\text { the-greatest }\end{array}$ & $\begin{array}{l}\text { Marsh.land- } \\
\text { scapes.--II } \\
\text { the.greatestri }\end{array}$ & $\begin{array}{l}\text { veryII } \\
\text { strong }\end{array}$ \\
\hline
\end{tabular}

Figure 8. The main factors intensifying the cryogenic processes activation

The vegetation damage is a universal type of the heat exchange change on the surface and in this meaning it is most often "a trigger" for cryogenic processes activation. Its role is double: under natural conditions it is one of the main stabilizers of permafrost conditions, performing the heat-insulating and fixing functions (a protective role of vegetation). After anthropogenic damage, the rate of vegetation cover restoration impacts permafrost processes attenuation $[15,25]$.

The predictive evaluations of their damaged areas, the rates of their development and attenuation along with the remediative, meliorative, environmental and engineering activities are used to stop these processes. The gradation of particular characteristics of the processes is based on quantitative or qualitative (points) indicators for carrying out their numerical comparison. A total score of these indicators is the extent of their activation in the territories under development. Indicators ranging should be brought in a number of tables, some of them are given below (Fig. 9-12).

The paramount indicator is the area of cryogenic processes damage which is estimated on five categories: from less than $5 \%$ (1 point) to more than $75 \%$ (9 points) of the territory under development.

The second important indicator is the processes development rate (Fig.9). It is clear, that the lower the rate, the less geoecological danger of economic development is. 


\begin{tabular}{|c|c|c|c|c|c|c|c|}
\hline \multirow[b]{2}{*}{$\begin{array}{l}\text { Processes } \cdot \pi \\
a\end{array}$} & \multicolumn{4}{|c|}{ Speeda } & \multicolumn{3}{|c|}{ Recurrencea } \\
\hline & $\begin{array}{l}\text { Slow } \\
\text { (1·point }) a\end{array}$ & $\begin{array}{l}\text { Average } \\
\cdot(2 \cdot \text { points }) a\end{array}$ & $\begin{array}{l}\text { Quickly } \\
\cdot(3 \cdot \text { points }) a\end{array}$ & $\begin{array}{l}\text { Catastro } \\
\text { phic } \\
\text { (4-points }) \text { a }\end{array}$ & $\begin{array}{l}\text { Rarely } \cdot \mathbb{T} \\
(1 \cdot \text { point }) \boldsymbol{a}\end{array}$ & $\begin{array}{l}\text { Periog } \\
\text { dically }(2 \cdot \\
\text { points)a }\end{array}$ & $\begin{array}{l}\text { Annually. } \\
\text { (3.points)a }\end{array}$ \\
\hline Thermoerosion, m/yeara & $a$ & $<5 a$ & $5-30 a$ & $30-100 a$ & $a$ & $a$ & 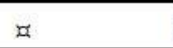 \\
\hline $\begin{array}{l}\text { Thermoabrasion, } \\
\text { m/yeara }\end{array}$ & 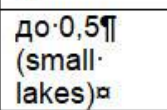 & $\begin{array}{l}0,5-2 \pi \\
\text { (large. } \\
\text { lakes)a }\end{array}$ & $\begin{array}{l}2-5 \pi \\
\text { (sea. } \\
\text { shores)a }\end{array}$ & $\begin{array}{l}\text { д०.10ף } \\
\text { (reservoirs } \\
\text { )a } \\
\end{array}$ & $a$ & $a$ & $a$ \\
\hline Thermokarst, $\cdot \mathrm{m} /$ yeara & $<\cdot 0,05 a$ & $0,05-0,1 a$ & $0,1-0,15 a$ & $0,15-1,0 a$ & $a$ & $a$ & 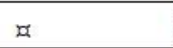 \\
\hline Solifluction, m/yeara & $<\cdot 0,2^{a}$ & $0,2-10 a$ & $>\cdot 10 a$ & m/daya & $a$ & $a$ & $\not$ \\
\hline Frost.heave, м/года & $<\cdot 0,05 a$ & $0,05-0,1 a$ & $0,1-0,5 a$ & $>0.5 a$ & $a$ & $a$ & $\not$ \\
\hline 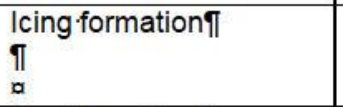 & $a$ & $a$ & $a$ & $a$ & $1 />5 \cdot$ years $a$ & $1 / 2-5 \cdot$ yearsa & $+\infty$ \\
\hline $\begin{array}{l}\text { Frost-crackingI } \\
a\end{array}$ & $a$ & $a$ & $a$ & $a$ & $\begin{array}{l}1 / 5-10 \\
\text { yearsa }\end{array}$ & $\begin{array}{l}1 / 3-5 \\
\text { yearsa }\end{array}$ & $+\infty$ \\
\hline Kurums, sm/yeara & $<\cdot 1 a$ & $1-3 a$ & $4-10 a$ & $>\cdot 10 a$ & $a$ & $a$ & $x$ \\
\hline
\end{tabular}

Figure 9. Development rate and recurrence of cryogenic processes

The permafrost processes, except for area distribution and The speed of development, influence the shape of a landscape in general, that can be estimated only qualitatively (Fig. 10). The first place in the transformation of natural landscapes into the inconvenient areas of land is won by thermoerosion because of the deep surface fragmentation, then the solifluction goes, turning landscapes into the impassable sites because of the pluvoon ground.

\begin{tabular}{|c|c|c|c|c|}
\hline \multirow{2}{*}{$\begin{array}{l}\text { T } \\
\text { Processes } \ \\
\text { T }\end{array}$} & \multicolumn{4}{|c|}{ The-impact'of'cryogenic·processes'on'landscapes? } \\
\hline & $\begin{array}{l}\text { Not } \\
(0 \cdot \text { points }) \alpha\end{array}$ & $\begin{array}{l}\text { Poor } \\
\text { (1 points)II } \\
\text { a }\end{array}$ & $\begin{array}{l}\text { Moderate- } 9 \\
(2 \cdot \text { points }) \mathbb{I} \\
\end{array}$ & $\begin{array}{l}\text { Strong } \\
(3 \cdot \text { points) II } \\
\text {. }\end{array}$ \\
\hline Thermoerosion, $\cdot$ & $a$ & $a$ & $+o$ & $+a$ \\
\hline Thermoabrasiono & $a$ & $+\alpha$ & $+a$ & $\alpha$ \\
\hline Thermokarsta & $a$ & $+\infty$ & $+\infty$ & $+\infty$ \\
\hline Solifluctiona & $\alpha$ & $+\infty$ & $+a$ & $+a$ \\
\hline Frost-heaver & $\alpha$ & $+\infty$ & $a$ & $a$ \\
\hline Icing formation & $+a$ & $+a$ & $+\infty$ & a \\
\hline Frost.crackinga & $+\infty$ & $+\infty$ & $a$ & $a$ \\
\hline Kurumsa & $o$ & $+\infty$ & $+a$ & $a$ \\
\hline
\end{tabular}

Figure 10. The impact of cryogenic processes on landscapes

The assessment of the work safety degree at engineering facilities (including accident rate) is shown in figur 11.

\begin{tabular}{|c|c|c|c|c|}
\hline \multirow{2}{*}{$\begin{array}{l}\text { Processes } \pi \\
a\end{array}$} & \multicolumn{4}{|c|}{ The'-accidents'emergence-dangera } \\
\hline & $\begin{array}{l}\text { Not- } \\
\text { (0.points)a }\end{array}$ & $\begin{array}{l}\text { I } \\
\text { Poor } \\
(1 \cdot \text { points }) \text { I } \\
a\end{array}$ & $\begin{array}{l}\text { I } \\
\text { Moderate } \cdot \pi \\
(2 \cdot \text { points }) \text { П } \\
\text { a }\end{array}$ & 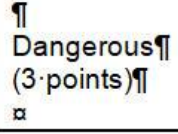 \\
\hline Thermoerosion, $\cdot a$ & a & $a$ & $+a$ & $+a$ \\
\hline Thermoabrasiona & $\alpha$ & $a$ & $+\infty$ & $+\infty$ \\
\hline Thermokarsto & $a$ & $+\infty$ & $+\infty$ & $+\infty$ \\
\hline Solifluctiona & $a$ & a & $+\infty$ & $+\infty$ \\
\hline Frost.heavea & $a$ & $a$ & $+\infty$ & $+\infty$ \\
\hline $\begin{array}{l}\text { Icing formationT } \\
\text { a }\end{array}$ & a & $+\infty$ & $+\infty$ & $+\infty$ \\
\hline Frost.crackinga & $+\infty$ & $+\infty$ & o & o \\
\hline Kurumsa & $a$ & $+a$ & $+a$ & $a$ \\
\hline
\end{tabular}

Figure 11. The accidents emergence danger 
Almost all processes which are listed in this table, except frost cracking and kurum formation, predetermine high accident rate of engineering facilities under considerable anthropogenic impacts[26].

The integrated assessment of geoecological situations has to include the attenuation rate of dangerous processes along with the efficiency of environmental activities for the protection against them owing to making competent engineering, remediation, etc. decisions (Fig. 12).

\begin{tabular}{|c|c|c|c|c|c|c|c|c|}
\hline \multirow[b]{2}{*}{ Processes-ा } & \multicolumn{4}{|c|}{ Attenuation-rate a } & \multicolumn{4}{|c|}{ Engineering·protectiona } \\
\hline & $\begin{array}{c}\text { Not } \\
(0 \cdot \text { points })^{x}\end{array}$ & $\begin{array}{c}\text { T } \\
\text { Slow } \\
\text { (1-points) } \\
a\end{array}$ & $\begin{array}{l}\text { T } \\
\text { Moderate } \\
\underset{(2 \cdot \text { points }) \pi}{ }\end{array}$ & $\begin{array}{l}\text { Tा } \\
\text { Fast } \\
\text { (3.points) } \\
\text { a }\end{array}$ & $\begin{array}{c}\text { Now } \\
(0 \cdot \text { points })^{a}\end{array}$ & $\begin{array}{c}\text { T } \\
\text { Badף } \\
(1 \text { points }) \Upsilon \\
a\end{array}$ & 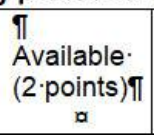 & $\begin{array}{c}\text { Good-T } \\
\text { (3.points })^{\text {a }}\end{array}$ \\
\hline Thermoerosion, $\cdot a$ & $a$ & $+\infty$ & $+\infty$ & $a$ & $+\infty$ & $+\infty$ & $+\infty$ & $a$ \\
\hline Thermoabrasiona & $+\infty$ & $+\infty$ & $+\infty$ & $a$ & $+\infty$ & $a$ & $\alpha$ & $a$ \\
\hline Solifluctiona & $+\infty$ & $+\infty$ & $\alpha$ & $+o$ & $+\infty$ & $+\infty$ & $a$ & $\alpha$ \\
\hline Frost'heavea & $+\infty$ & $a$ & 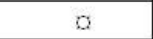 & $\alpha$ & $+\infty$ & $+\alpha$ & $\alpha$ & $\alpha$ \\
\hline Icing formation & $+o$ & $+\infty$ & $a$ & $\alpha$ & $a$ & $a$ & $+\infty$ & $+\infty$ \\
\hline Frost·cracking & $+\infty$ & $\alpha$ & $\alpha$ & $+\alpha$ & $+a$ & $\alpha$ & $+a$ & $a$ \\
\hline
\end{tabular}

Figure 12. Cryogenic processes attenuation rate and availability of engineering protection protection

The natural attenuation can be connected with the consumption of their main resource, i.e. ice, along with the low negative temperatures, rapid vegetation restoration, relief alignments [25].

\subsection{The assessment and mapping of geoecological situations at regional level}

At the overview-regional scale of research, the evaluation and mapping of ecological situations are based on the identification of territories in accordance to permafrost, climatic, landscape conditions of processes activation and anthropogenic loading degree. The potential danger of cryogenic processes manifestation in the territory of Russia cryolithozone is defined by the extent of their activation and a combination of the most typical processes within various natural complexes [15, 25].

On the colour small-scale map of the permafrost zone of Russia (fig. 13), five groups of potential processes activation are allocated: from weak to very strong. The assessment of the extent of permafrost processes activation varies for plain and mountainous territories. On the plains, the whole area of a landscape is estimated. For highlands, the activation of the processes is considered separately within a mountainous terrain and in valleys $[5,6,7,15]$. 


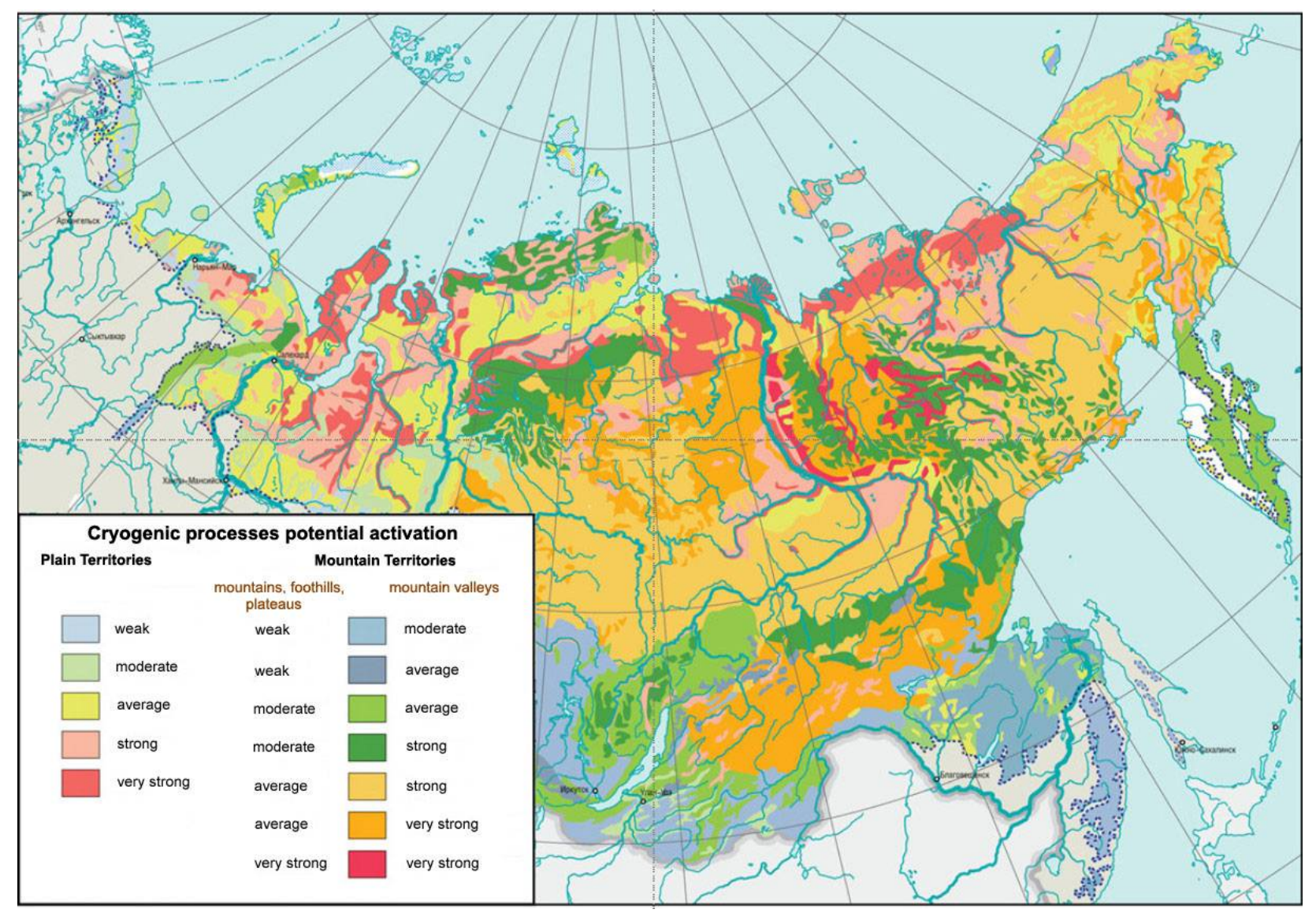

Figure 13. The map of cryogenic processes activation

The distribution of various combinations of the main cryogenic processes is presented on the map (fig. 14). These combination groups are united in 11 groups according to the zonal and regional varieties of the permafrost, landscape and climatic conditions. They are characterized by different variations of eight most ecologically and technologically dangerous and typical cryogenic processes. In the legend to this map, the first six groups characterize the processes peculiar for plain landscapes, and the groups from the 7th to 11th are for mountains, foothills, including the river valleys dividing these territories [15]. 


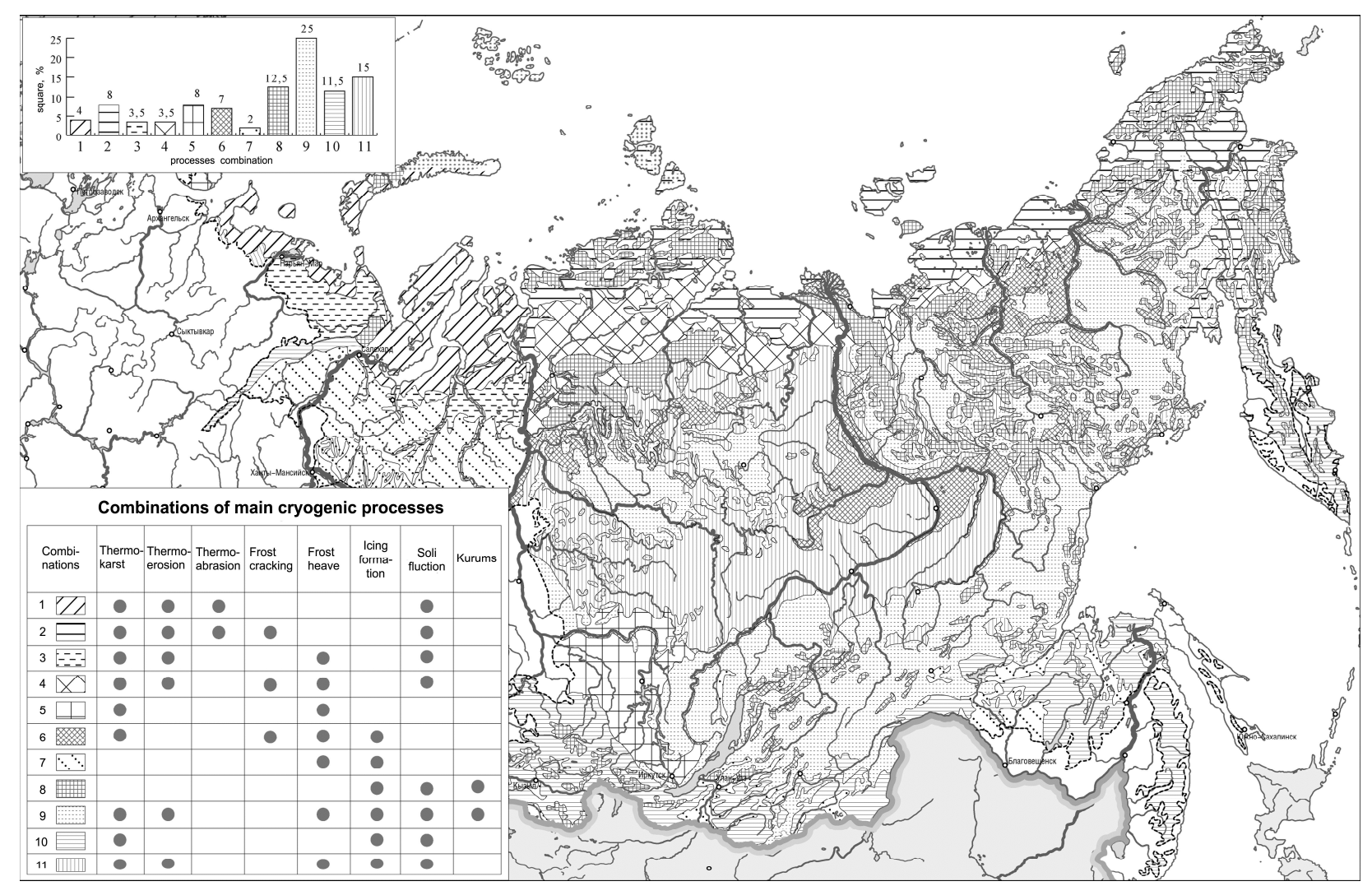

Figure 14. The map of combinations of the main cryogenic processes

GIS-analysis of these groups of processes (fig. 15.) leads to the following conclusions.

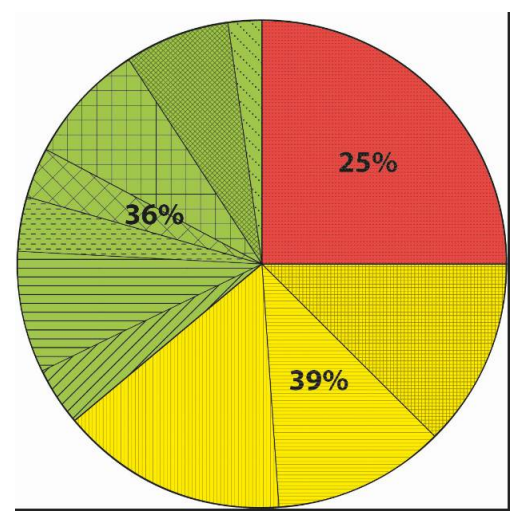

Figure 15. The combinations groups of the cryogenic processes

The first group occupies a quarter of the permafrost zone (fig. 16) where the combination of mountainous and valley processes take place, i.e. thermokarst, thermoerosion, frost heave, icing formation, solifluction, kurums, that are spread in a mountainous-highland belt of Central Siberia, the Far East, Baikal and the Transbaikal ridges [14,27]. It corresponds to the fact that highlands occupy the most part of the permafrost zone. The development of these territories is highly localized, though there are a lot of problems with the construction, but they rather rarely occur. The territories of the first group have small environmental hazard. 


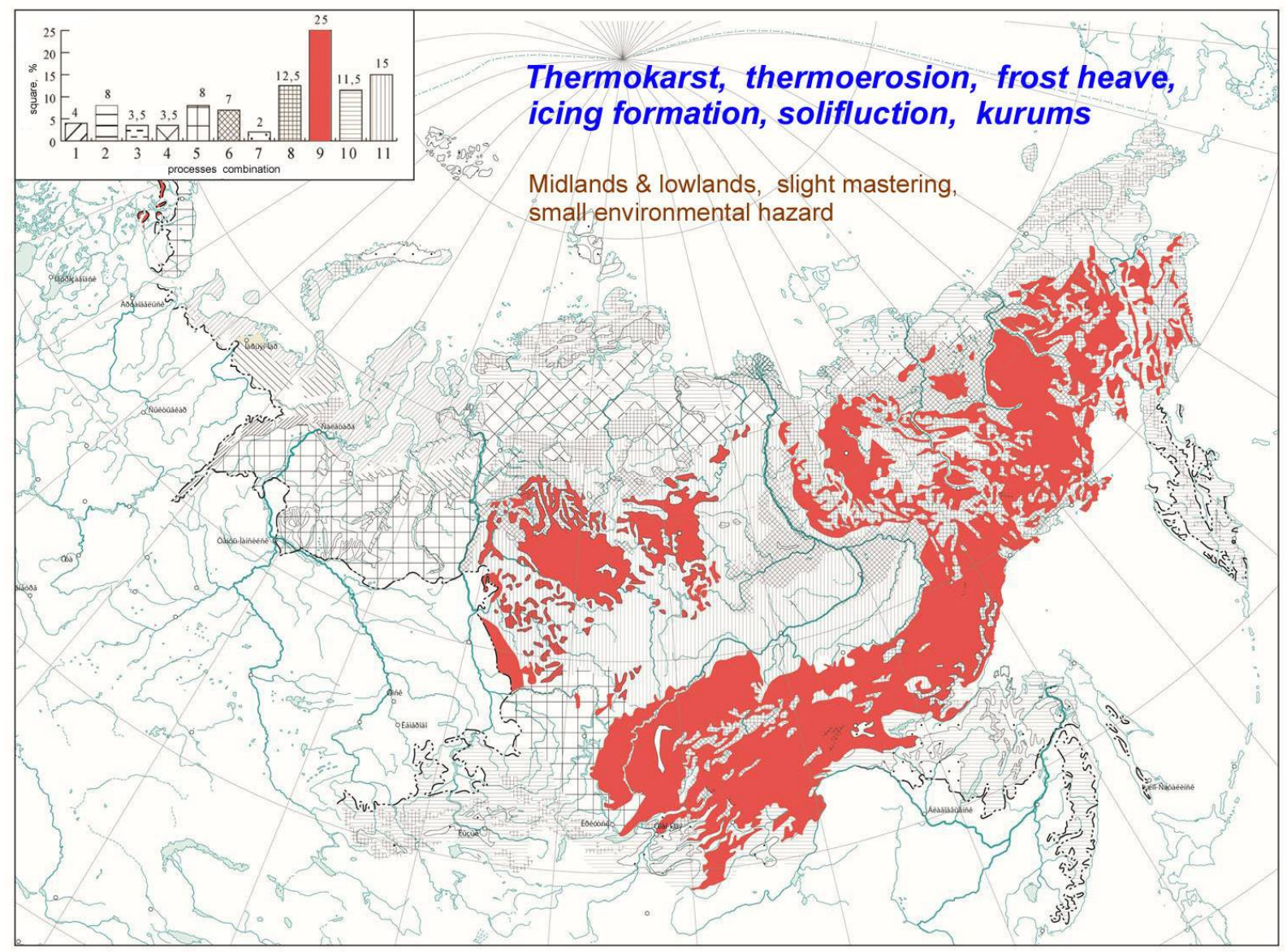

Figure 16. The first group of processes combinations

The second group (fig. 17) includes three groups of processes combinations which occupy the greatest part of the permafrost zone - 39\% (fig. 15). These are highlands too, but different in morphology. There are highlands and loaches of the northern low mountains where the slope processes and icing in the valleys are typical. The development is insignificant here, the problems of construction are very rare. The territories of the second group of processes have moderate environmental hazard. 


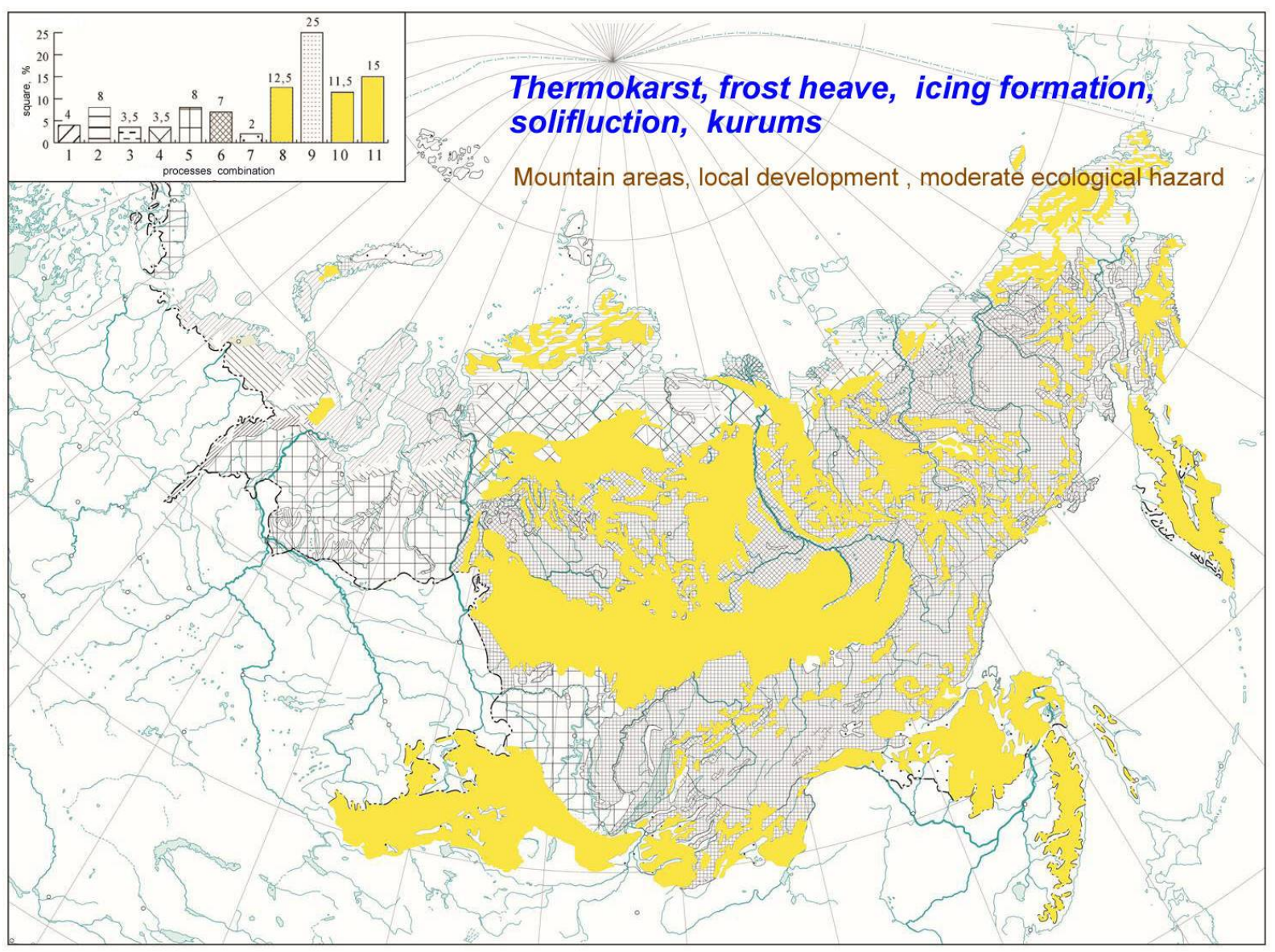

Figure 17. The second group of processes combinations

The third group (fig. 18) is comprised of the processes each of which occupies less than $10 \%$, but their total area is $36 \%$ of the Russian cryolithozone (fig. 15). 


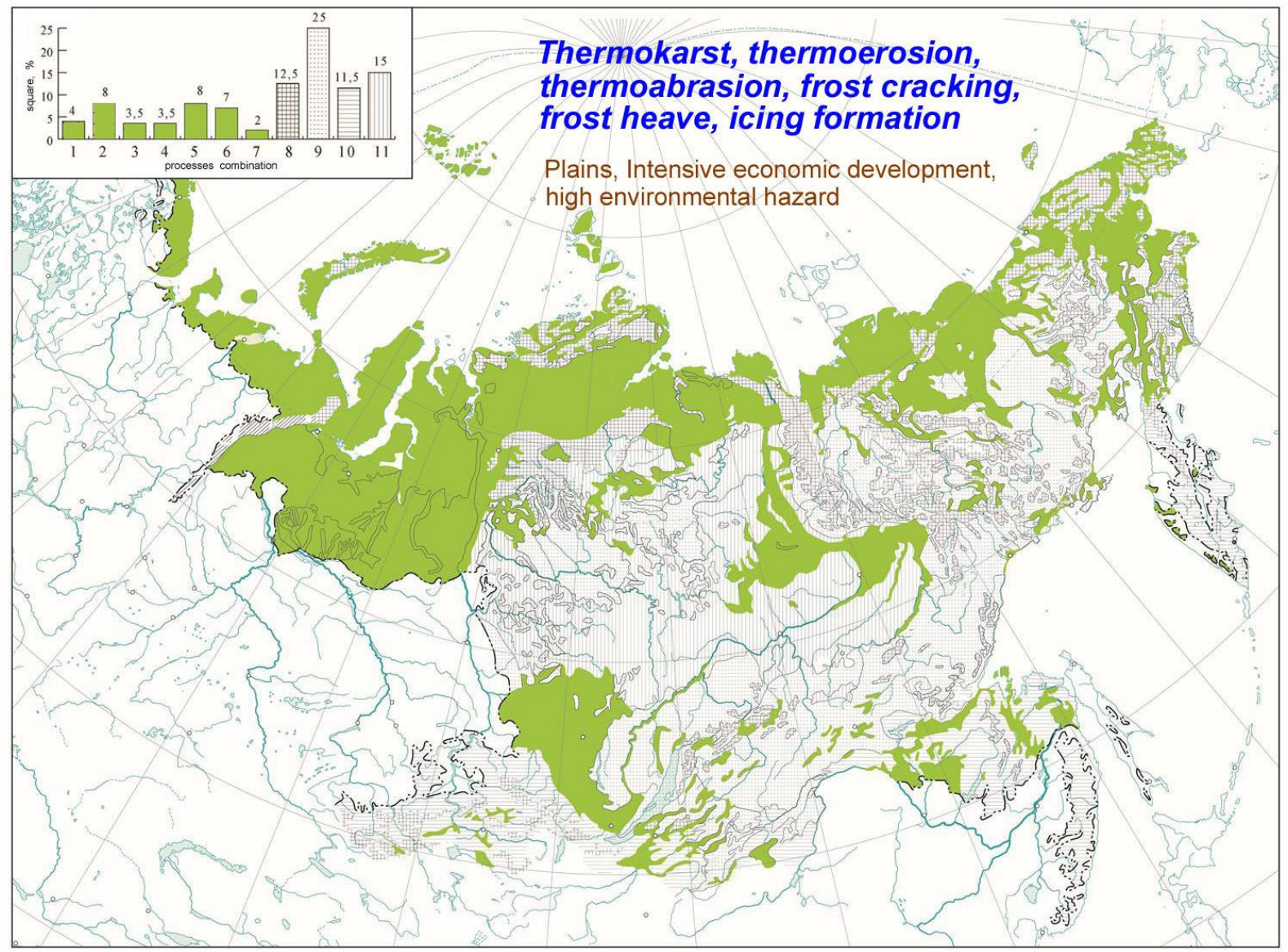

Figure 18. The third group of processes combinations

Their diagnostics is the most difficult, as this group is the most numerous in the number of combinations entering it (numbers from 1 to 7). In terms of geomorphology, they are plains and mountain hollows. It is here that there is an active mastering of the territory not only due to the mineral wealth, but also to rather convenient conditions for development. Respectively, the activation of cryogenic processes manifests itself to the utmost. They occupy the largest areas, their rates are large, the combinations are various, the threats to engineering facilities are also diverse [27].

\section{Discussion}

Thus, the diagnostics of geoecological situations in the permafrost zone in the overview-regional research is based on the assessment of the anthropogenic cryogenic processes activation of through studying the area affected by them, their rate of development, natural landscapes damage, threats to the functioning of engineering structures.

At the overview scales of the research, the most significant permafrost factors are:

- the area of the permafrost distribution in $\% \%$ from continuous to island;

- the annual mean temperature of the permafrost from below $-11^{\circ} \mathrm{C}$ up to 0 ० $\mathrm{C}$ with separate scale for plains and mountains;

- the ice content of the permafrost with the intervals for weakly, mid- and strongly icy types, including monomineral ice.

The hazard severity of the situations increases with the growth of the area and the ice content degree of the permafrost, their approach to $0^{\circ} \mathrm{C}$.

The basis for the diagnostics and mapping of geoecological situations are landscapes, and the instrument of diagnostics is the thawing depth. The latter is chosen by us as the most sensitive indicator of the situations change in space and time.

At the local level of the research, the range of estimative factors is wider. It is the ice content degree and temperature of the permafrost, the depth of seasonal thawing or freezing, the relief, the heat-insulating 
properties of the vegetation and the rate of its self-recovery, the bioclimatic indicators etc. During the process of evaluative mapping of the permafrost contents, various techniques are used: methods of statistical calculations, indicative signs, maps-indicators, scientific hypotheses, extrapolations, etc. The ecological indicators are generally defined on the basis of expert estimates and rely on the long-term experience of regional research. On the basis of the analysis of the chosen factors, the integrated indicator of their cumulative influence is calculated. It can be either the simple sum of factor points or their geometric mean, or the calculated coefficient developed in the multiple regression equation. For the determination of points dimension it is proposed to use a cent scale.The graphic-analytical method of assigning scores against the background of the interval 100-cent scale allows us to commensurate numerical scores on difficult-to-match scales, as well as to supplement traditional points with an estimate of their own weight. The latter technique of the calculation of the total score, undoubtedly, will interest the reader.

\section{Conclusions}

The ecological component of the majority of geocryologic research consists in the assessment of the cryogenic processes manifestation of observed in nature. The paper reveals the experience of carrying out diagnostics and mapping of the permafrost-ecological state based on the identification of the areas of anthropogenically provoked cryogenic processes, ranging the extent of their activation and the combinations of the most typical processes within various landscapes. Scientific and methodological approaches of this avaluation find application in engineering geocryology, at predesign stages of the research, in the nature protection institutions for the elaboration of the competent strategy of the cryolithozone development.

The paper reveals the experience of permafrost-landscape mapping in different scales of research: from atlas to large-scale. The atlas maps, designed on a common landscape basis, have universal value, allowing us to arrange, analyze and generalize the information about the permafrost zone landscapes. Their content, the chosen indicators, classifications, gradation of values are developed taking into account the possibility of their further application for geoecological estimates, for taking administrative decisions. They are actively used in the educational process as visual aids.

\section{Acknowledgments:}

This research was partially supported by Russian Science Foundation grant No. 18-05-60080

The authors express deep gratitude to Natalia Koroleva for her professional cartographical work.

\section{The Authors' Contributions:}

Conceptualization, Nellie Tumel ; Methodology, Nellie Tumel and Larisa Zotova; Writing - original draft, Nellie Tumel ; Writing - review \& editing, Larisa Zotova

Nellie Tumel develops the ideas of atlas mapping, the content of small-scale legends and mapsLarisa Zotova is the author of the technique of large-scale evaluation and mapping along with the methods of expert numerical scores development.

\section{Conflict of Interest}

The authors declare no conflict of interest.

\section{References}

1. Geocryologic Map of the USSR. 1: 2.5 million / Edition E.D. Yershov. Vinnytsia, 1997 (in Russian).

2. Geocryologic Map of the USSR. 1:5 000 000. / Under the editorship of I.Ya. Baranov. GUGK, 1977 (in Russian).

3. Circum Arctic Map of Permafrost and Ground Ice conditions, scale 1:10 000000 / Ed. by J. Brown, O.J. Ferrians, Jr., J.A. Heginbottom, E.S. Melnikov. Interior-geological survey, Reston, Virginia, 1997.

4. Cryolithologic Map of the USSR (for area of permafrost). 1: 4 million, 1985 (in Russian).

5. Ecological Atlas of Russia. 2002. SPb: CJSC Karta publishing house, 2002. pp. 50-54 (in Russian).

6. National Atlas of Russia. Volume 2. Nature, ecology. Section "Snow. Ice. Permafrost". Moscow, Roskartografiya, 2007. pp. 240-242, ISBN 5-85120-216-5 (in Russian). 
7. Ecological Atlas of Russia. Moscow, LLC Feoriya, 2017. pp. 183-188, ISBN 978-5-91796-034-0 (in Russian).

8. Atlas of the Yamalo-Nenets Autonomous Area. Omsk, Federal State Unitary Enterprise Omsk Cartographical Factory, 2004 (in Russian).

9. Atlas of Khanty-Mansi Autonomous Okrug. Volume II. Nature. Ecology. Moscow, LLC NPF TalkaTDV, 2004. pp. 53-57,59 (in Russian).

10. Siberia. Atlas of Asian Russia. Novosibirsk, Feoriya, 2007, ISBN 5-287-00413-3 (in Russian).

11. The Russian Arctic in the 21st century: natural challenges and risks of development. Atlas. Moscow, 2013. pp. 54-69 (in Russian).

12. Landscape Map of the USSR. 1:4 000 000. / Under the editorship of. A.G. Isachenko. Moscow, GUGK, 1988 (in Russian).

13. Geocryology of the USSR. Central Siberia. Moscow, Nedra. 1989. 463 p (in Russian).

14. Geocryology of the USSR. Western Siberia. Moscow, Nedra. 1989. 454 p. ISBN 5-247-00432-9

15. (in Russian).

16. Tumel, N.V. Permafrost geoecology: training aid for bachelors and masters / N.V. Tumel, L.I. Zotova. 2nd ed. Moscow, Yurite. 2017. 220 p. ISBN 978-5-534-04227-6 (in Russian).

17. Tumel, N.V., Zotova, L.I., Grebenets, V.I. Concept of stability of cryogenic landscapes. Geographical scientific schools of the Moscow University. Moscow, 2008. pp. 139-144 (in Russian).

18. Shpolyanskaya, N. A., Zotova, L.I. Map of potential stability of landscapes of a cryolithozone of Western Siberia. Vestn. Mosk. un-tha. Series 5, Geogr. 1994. No. 1. P. 56-65 (in Russian).

19. Shpolyanskaya, N.A., Zotova, L.I. 2010. Development of the North: how to keep balance in nature. Ecology and life. Volume 11. pp. 66-73 (in Russian).

20. Influence of climate on the development of permafrost landscapes of Central Yakutia / Gavrilov, M.K., Bosikov, N.P., Fedorov, A.N., et al. Yakutsk, IMZ Siberian Branch of the Russian Academy of Science, 1996. p. 152 (in Russian).

21. Simonov, Yu. G. Numerical scores in applied geographical research and the way of their development. Vestnik Mosk. un-tha. Series 5. Geography. 1997. No.4. pp. 7-10 (in Russian).

22. Zotova a, L. I. Theoretical and applied aspects of expert geoecological assessment of the hazard of economic development within the new educational program. Proc. of the Fourth conf. of geocryologists of Russia. Vol. 3. P. 9. Environmental Issues of the Cryolithozone. Moscow, Mosk publishing house. un-that, 2011. pp. 224-231 (in Russian).

23. Zotova, L. I., Koroleva, N.A., Dedyusova, S.Yu. Evaluation and mapping of crisis ecological situations in the territories of gas-field development in the Cryolithozone. Vestnik Mosk. un-tha. Series 5. Geography. 2007. No. 3. pp. 54-59 (in Russian).

24. Zotova, L. I., Dedyusova, S. Yu. Evaluation of Critical Ecological Situations in the Tyumen Northern Cryolithozone under Economic Development. Melnikov, P.I. (ed.). Tenth International Conference on Permafrost. 2012. Volume 2: The Northern Publisher. Salekhard, Russia. pp. 543-548. ISBN: 978-5905911-02-6

25. Kochurov, B.I., Tumel, N.V., Zotova, L.I. Ecodiagnostics of dangerous geoecological situations in the economic development of the cryolithozone. Regional Environmental Issues. No. 4, 2015. pp. $157-164$ (in Russian).

26. Tumel, N.V. Activation of dangerous cryogenic processes. Geography, society, environment. 2004.Volume 1. Structure, dynamics and evolution of natural systems. Moscow, Izd. house "Gorodets". pp. 344-357 (in Russian).

27. Natural hazards of Russia. Geocryological dangers of Russia. Thematic volume. Ed. by L. C. Garaguly, E. D. Yershov. Moscow, Publishing company "CROOK", 2000. 316 p (in Russian).

28. Tumel, N.V., Zotova, L.I. Cryolithozone Geosystems Response on Anthropogenic Impacts. Arctic, Subarctic: mosaic, contrast, variability of the Cryosphere: Proceeding of the International Conference/V.P. Melnikov and D.S. Drozdov (ed.) Tyumen: Epoha publishing house. 2015. pp. 379- 382. ISBN: 978-59906392-0-1 